\title{
ECONOMIC DEVELOPMENT AND ECONOMIC GOVERNANCE THROUGH THE EXAMPLE OF THE CITY OF GYŐR
}

\section{GAZDASÁGFEJLESZTÉS ÉS GAZDASÁGI KORMÁNYZÁS GYŐR PÉLDÁJÁN}

\author{
Dávid FEKETE ${ }^{\mathrm{a}}$ \\ a'Széchenyi István University, Department of Regional Science and Public Policy, fdavid@sze.hu
}

Cite this article: Fekete, D. (2018). Economic Development and Economic Governance Through the Example of the City of Györ. Deturope, 10(1), 97-115.

\begin{abstract}
Since the 1990s the metropolitan region and its governance has got into the focus of regional science again. Nowadays a newer wave of metropolitan governance is authoritative, which has exceeded the former administrative-territorial planning aspects, and has appeared on the scene as the mechanism of economic development policy. Examining the development stages of regional policy it is well-known that the classical (modern) approach was superseded by the postmodern one. While the national methods applied in the classical period were characterized by strictness, central regulation, indirect regulation of the market (Fordist approach), in the postmodern period flexibility, decentralization and direct regulation have come to the fore (Post-Fordism). In the postmodern period the state level also takes its role in the financing of innovation and research\&development, and the notions of networking and competitiveness are coming more and more to the fore.

In this article I analyze these processes through the case study of Györ. After the theoretical introduction I examine the tools of economic development and economic governance in the Györ metropolitan region. Activities observed in Györ can strengthen the view-point that the processes of economic development and economic governance have nowadays been going on in parallel with each other. Moreover, the coordinating activities of local authorities can be observed in the work of organizations that support economic governance. In the course of the research it was also confirmed that built infrastructure can serve as a fundamental condition for the cooperation of network-systems that operate the governance system of a municipality.
\end{abstract}

Keywords: economic development, economic governance, Győr metropolitan region, automotive industry centre, vision

\begin{abstract}
Napjainkban a nagyvárosi régiók kormányzása újra a regionális tudományi kutatások fókuszpontjában helyezkedik el, sok kutató szerint reneszánszát éli a terület. A nagyvárosi kormányzás jelenlegi szakaszában a korábbi közigazgatási szemléletet meghaladva a gazdaságfejlesztés került a városok fókuszába, s az önkormányzati szereplők mellett a gazdasági és a civil szektor szereplői is bekapcsolódtak, s egyfajta hálózatos kormányzás figyelhető meg a legtöbb helyen. A regionális politika fejlődési szakaszait vizsgálva közismert, hogy a klasszikus (modern) megközelítést a posztmodern váltotta fel. Míg a klasszikus időszakban alkalmazott állami módszereket a merevség, központi szabályozás, a piac közvetett szabályozása jellemezte (fordista szemlélet), addig a posztmodern időszakban inkább a rugalmasság, a decentralizáció és a közvetlen piacszabályozás került előtérbe (posztfordizmus). A posztmodern időszakban az innováció és a kutatás-fejlesztés finanszírozásából már az állami szint is erőteljesen kiveszi a szerepét, s egyre inkább a hálózatosodás, a versenyképesség fogalmai kerülnek elötérbe.

A tanulmányban a fenti folyamatok győri megjelenését, egymáshoz való viszonyát vizsgálom. Az elméleti felvezetést követően bemutatom a gazdaságfejlesztés és a gazdasági kormányzás Győrben megfigyelhető eszközeit, azok legfontosabb jellemzőit és szereplöit.
\end{abstract}

Kulcsszavak: gazdaságfejlesztés, gazdasági kormányzás, győri nagyvárosi régió, járműipari központ, jövőkép 


\section{INTRODUCTION}

The centres of power concentrating around urban regions which are often related to the operation of international enterprises play a significant role in the evolution of Hungary's economic achievement. Examples are AUDI in Györ, Mercedes in Kecskemét, Takata and Bosch in Miskolc. There have been more and more researches aimed at the achievements of the country's economic flagships, with special attention to their regional dimensions. There are countless research examples related to the economic region of Györ. (Filep et al., 2013; Czakó, 2014)

Besides the established multinational enterprises the national supplier network of SMEs (small and medium-sized enterprises) also play a significant role in the development of certain metropolitan regions, as well as the economic environment in the development of which the local self-government, government bodies, enterprises, the representatives of the academic sphere together with the educational institutions also take an active part. Nowadays the new types of cooperation of these organisations have attracted the researchers' attention. These types of cooperation are driving certain city regions towards economic governance. As it was proved by a research completed in 2015 all these types of cooperation present different operational models in certain European automotive centres.

Researchers have still been kept busy by questions on how local economic environment can contribute to the economic performance of the region, moreover, how it is worth interfering with the local economic relationships. The application of which economic development tools proves to be good investment? In what ways can economic governance as a novel initiative help? The topic of the present article is the processes observed in Györ which are related to the development of the economic environment, the economic development measures and the shift towards economic governance.

\section{ECONOMIC DEVELOPMENT AND ECONOMIC GOVERNANCE}

The aspects of metropolitan economic development and governance (such as governance structures, organizational frameworks, methods of public policies, ethnic diversity and economic development etc.) have recently been widely discussed. (Knieling, 2014; Pike et al., 2007; Ash, 1999; Salet et al., 2003; Bacsi, 2017; Bartik, 1991; Montalvo - Reynal-Querol, 2005) There have been active scientific debates (Massey, 1988; Bajmócy et al., 2017; AyusoColl, 2016; Mattoon, 1995; Jessop, 1997; Ostrom, 2010) about these issues.

Since the 1990s the metropolitan region and its governance have got into the focus of regional science again. According to many authors the renaissance of metropolitan governance that began at that time has been going on nowadays as well. (Lefèvre, 1998; Pálné, 2008; Desai et al., 2011; Herrschel-Newman, 2002) The continuous regional expansion 
of the cities, the development of information and communication technologies, the failure of the welfare state, or the gradual strengthening of European integration and globalisation have all had the influence that there is a need for new regional participants which can manage, govern bigger areas from an economic point of view by exploiting the economies of scale (Lefèvre, 1998).

Examining Enyedi's stages of city growth, the current stage is the age of the urbanisation of globalised world in which the power centres controlling global processes are not primarily related to countries but to metropolitan regions agglomerating influential transnational corporations. For today some of the cities have "stepped out" of the national city system and linked up with each other at an international level to form a global network of cities (Enyedi, 2012). According to Porter, local clusters play a significant role in the global economy (Porter, 2000). Nowadays villages can be characterised as rural settlements integrated to cities which directly contribute to the development of the whole city region. In turn, strong cities more and more determine their rural environment. The cooperation can extend to numerous areas, such as common provision of public services, energy management, economic development, etc. (Faragó, 2006). Today the city and its region specially stand together, interactions between the areas are becoming more and more frequent, accordingly, what influence a city can have on its own environment is an important aspect.

Nowadays a newer wave of metropolitan governance is authoritative, which has exceeded the former administrative-territorial planning aspects, and has appeared on the scene as the mechanism of economic development policy. The concept according to which city regions must absolutely become one administrative unit formerly caused conflicts, but has now been eliminated: governance problems are to be solved via informal partnerships, and the primary aim is to stimulate economic development and cooperation between the different spheres in the theoretical ground of the new regionalism and Post-Fordism. The governance practice of the present also shows that the solutions, governance structures of different ages often coexist even today. Although the current system is based on volunary participation, some of the state policies still use different incentives to influence the governance of metropolitan regions (Somlyódyné, 2011).

The topic of metropolitan governance is strongly related now to governance-type cooperation. According to this, the local governments establish network governance in cooperation with the participants of local business and civil sectors which surpass the strict administrative structures. The cooperation between local governments is more frequently realised in the form of network. At similar governance-type city region governance the targets are still set by the local governments, but the representatives of the already mentioned two sectors are involved in the common decision-making process as important partners. The 
decisions are often made in relaxed horizontal structure which rarely creates independent organisations; it is rather characterized by a horizontal coordination. The governance methods taken from the market dominate in such cooperation (Somlyódiné, 2008). According to Pálné (1999), an important reason for the replacement of former hierarchical structures with the relaxed horizontal ones was that local resources had been more intensively applied in settlement development. A characteristic feature of the governance type metropolitan governance is that it is mostly realised without governmental institutions, by the cooperation among the participants. This coordination is called institutional collective action by Feiock (2004). Nowadays, it is getting more and more emphasis that in many instances the network governance of metropolitan city regions operates separately from the official structures governing the city, especially in the metropolitan city region of the USA (Oakerson, 2004). At the same time at national level the local government's role of a catalyst is rather characteristic as it is often the city government that takes the lead in the cooperation in the topic of economic development (Fekete, 2017c). According to some expert, the significant cooperation between local authorities and local companies could damage the level of local democracy, because interests of companies are sometimes more important than interests of local people (Crouch, 2011).

Examining the development stages of regional policy it is well-known that the classical (modern) approach was superseded by the postmodern one. While the national methods applied in the classical period were characterized by strictness, central regulation, indirect regulation of the market (Fordist approach), in the postmodern period flexibility, decentralization and direct regulation have come to the fore (Post-Fordism). In the postmodern period the state level also takes its role in the financing of innovation and research\&development, and the notions of networking and competitiveness are coming more and more to the fore (Rechnitzer-Smahó, 2011). Brenner (2003) also emphasises that instead of the institutional structures of the Keynesian-Fordist period economic priorities such as territorial competitiveness come to the centre of metropolitan governance.

On the basis of the above ideas, it is worth mentioning how the public sector tried to influence the local economy in the above mentioned two periods. As it can be seen in Tab. 1, economic development of the modern times can rather be conceived as a supply-oriented policy which is mainly characterized by the building of hard infrastructure, top-down approaches, and the economic participants are the beneficiaries. The economic governance of the present postmodern period is rather demand-oriented: it pays more attention to soft investments, allows bottom-up initiatives, and establishes network cooperation among the economic, higher educational, research-development institutions and organisations (Bajmócy, 2011; Lengyel, 2010; Lengyel-Rechnitzer, 2004). In my opinion, all these - of course - do not 
mean that tools used in the modern period would disappear, moreover, they often strengthen themselves parallel with the interventions of the postmodern period. Although the interventions based on economic governance are more and more characteristic, most of the cities still make ,economic development strategies”.

Table 1 The interventions of modern economic development and postmodern economic governance

\begin{tabular}{|l|l|l|}
\hline & $\begin{array}{l}\text { Modern economic } \\
\text { development }\end{array}$ & $\begin{array}{l}\text { Postmodern economic } \\
\text { governance }\end{array}$ \\
\hline Philosophy of intervention & Supply-oriented & Demand-oriented \\
\hline Main tools of intervention & $\begin{array}{l}\text { Development of hard } \\
\text { infrastructure }\end{array}$ & $\begin{array}{l}\text { Soft investments, } \\
\text { establishment of economic } \\
\text { environment }\end{array}$ \\
\hline Direction of intervention & Top-down & Bottom-up \\
\hline $\begin{array}{l}\text { Beneficiary groups of } \\
\text { intervention }\end{array}$ & Economic operators & $\begin{array}{l}\text { Economic, higher education, } \\
\text { research-development } \\
\text { institutions and organisations }\end{array}$ \\
\hline
\end{tabular}

Source: own editing

According to Bajmócy (2011) nowadays the third wave of the local economic development can be observed. The first wave between the 1960s and the beginning of 1980s was focusing on the resources outside the region: it tried to motivate the involvement of external corporations by building physical infrastructure, almost exclusively by using community resources. The tools of the first wave were mainly in the interest of large enterprises: discounts, cheap premises and labour, moreover, the development of infrastructure and settlement marketing promoting these measures (see Tab. 2).

On the contrary, the second wave disposed of a more integrated approach. It made efforts to integrate the settled large enterprises, to develop the SME network related to it. The period between the beginning of the 1980s and the middle of the 1990s was characterized by the development of evolving new key sectors, a more targeted choice of investors and the extensive support of SMEs. At the same time, project-based financing dominated by the public sector was still typical, but the development of the so-called soft factors (such as labour training) also appeared. Today's local economic development measures are determined by the competitiveness-based strategic approach. Because of the strict nature of the competition rules of the EU the state's direct intervention in market processes was more and more suppressed in the third wave, and the emphasis is placed on the development of local business environment and innovation potential of enterprises and on the establishment of a liveable environment. At the same time, the role of public sector is still decisive, but together with the strong partnership of business and civil sectors (Bajmócy, 2011). 
Table 2 Stages of development of local economic development policy

\begin{tabular}{|c|c|c|c|}
\hline & $\begin{array}{l}\text { Stage } 1(1960 \mathrm{~s}-\text { early } \\
1980 \mathrm{~s})\end{array}$ & $\begin{array}{l}\text { - Stage } 2 \text { (early 1980s - } \\
\text { mid 1990s) }\end{array}$ & $\begin{array}{c}\text { Stage } 3 \text { (from the mid } \\
1990 \mathrm{~s} \text { ) }\end{array}$ \\
\hline Characteristics & $\begin{array}{l}\text { - Involvement of non- } \\
\text { regional resources } \\
\text { - Aim: resettlement of } \\
\text { large companies } \\
\text { - Building physical } \\
\text { infrastructure } \\
\text { - Almost exclusively } \\
\text { community resources }\end{array}$ & $\begin{array}{l}\text { - A more integrated } \\
\text { approach } \\
\text { - Nesting of resettled } \\
\text { large companies } \\
\text { - Development of SME } \\
\text { network } \\
\text { - Project-based financing } \\
\text { dominated by the public } \\
\text { sector }\end{array}$ & $\begin{array}{l}\text { - Competitiveness- } \\
\text { based strategic } \\
\text { approach } \\
\text { - Role of public } \\
\text { sector is } \\
\text { determinant } \\
\text { - Strong partnership } \\
\text { of business and } \\
\text { civil sector }\end{array}$ \\
\hline Devices & $\begin{array}{l}\text { - Preferences, cheap site } \\
\text { and labour } \\
\text { - Building infrastructure } \\
\text { - Settlement marketing } \\
\text { popularizing } \\
\text { provisions }\end{array}$ & $\begin{array}{l}\text { - Development of new } \\
\text { key sectors } \\
\text { - A more targeted choice } \\
\text { of investors } \\
\text { - Wide support of SMEs } \\
\text { - Development of the so- } \\
\text { called soft factors }\end{array}$ & $\begin{array}{l}\text { - Development of } \\
\text { local business } \\
\text { environment and } \\
\text { innovation potential } \\
\text { of enterprises }\end{array}$ \\
\hline
\end{tabular}

Source: own editing, on the basis of Bajmócy (2011)

Beside economic governance, cultural governance plays a more and more important role in the life of metropolitan areas (Moon, 2001). That is the reason why an organization from the area of culture was chosen for analysis in the last part of the paper.

\section{OBJECTIVES AND METHODS}

The objective of the study is to present the processes and correlations of economic development and economic governance within a metropolitan region through a case study of Györ, after founding the theoretical bases. In the theoretical introduction the concepts of economic development and economic governance, the related attributes, and the most important differences between the two concepts are presented, as well as the positions of the two activities in the adequate stages of the development of regional sciences. After that the situation in Győr is observed. First of all, those economic development factors are presented, which were realized in the past decade, then the organisations which are evidence of the shift towards economic governance in the framework of a comparative analysis: Györ Automotive Career Model Cooperation, Győr District Employment Pact, Győr Local Community and Arrabona EGTC (Arrabona European Grouping of Territorial Cooperation). The viewpoints of the comparative analysis are the following: city region focus, quality of participants (public sector, economic organisations, civil sector), sustainability, sector-specific nature. The research reveals the present Györ model of economic governance, and the results related to the studied organisations can give clues in connection with the further development of the model.

During the research process the basis of the theoretical research was national and international literature related to metropolitan regions, their governance and economic activity. During the empirical research the economic development tools and measures of Györ 
were represented on the basis of the related literature and the data collection by the author, while during the examination of organisations related to economic governance the documents of the given institutions and the materials regulating their operation were used.

\section{RESULTS}

\section{The example of Győr}

Györ is the 6th biggest city in Hungary. It is a city with county rights, the capital of GyörMoson-Sopron County and the Györ district. The number of inhabitants in Györ is 129.372 ( $\mathrm{KSH}, 2015)$, its area is $174,5 \mathrm{~km} 2$. Győr is situated in the Budapest-Vienna-Bratislava triangle and for centuries it has been an important economic and arterial centre. The city has direct access to the motorway in the direction of Budapest and Vienna, it has its own airport (Győr-Pér Airport) and its own river port (Port of Győr-Gönyü). Györ is the centre of Hungary's strongest economic region its largest employer is AUDI Hungária which in 2017 directly employed more than 12.000 people and almost another ten thousand indirectly. AUDI has special economic and social effects on Györ (Czakó 2014). The fact that from among the 23 cities of Hungary having county rights, the amount of business tax paid was the highest in Győr, showing growing tendencies, indicates the strength of Győr. In 2016, 145 billion HUF (500 million EUR) of business tax was generated by the cities having county rights, of which 22 billion HUF (73 million EUR) was realised by Győr (Korsós, 2016).

Figure 1 Location and accessibility of Győr.

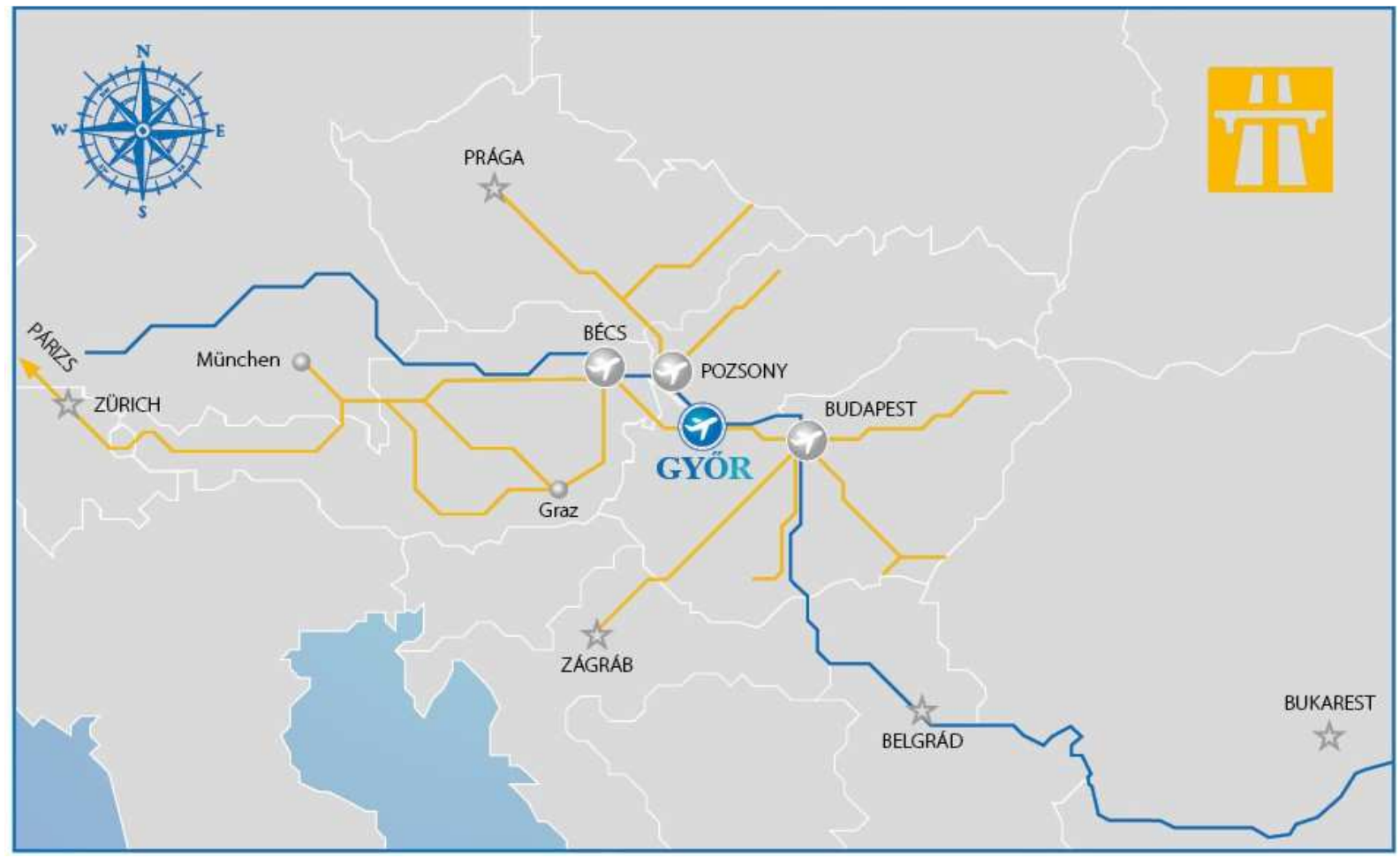

Source. Municipality of Győr 
The economic region of Györ has become one of the most determinant economic power centres of Hungary. According to researchers examining the economic development of the city, the concentration of Győr's regional capital showed a significant density even in the last centuries, thus the city could successfully manage the different transitions (it could become a commercial city, then an industrial city from a military centre by this). Győr was helped by the social capital due to which the further intensity of the interactions among the different participants could move at a high level (Rechnitzer, 2016). All the above ideas are in line with the statement according to which one of the most important key elements of growth is that the region should be characterised by the coordinated, efficient cooperation of the government, municipalities and the participants of the educational and economic sphere parallel with the regional establishment of technological and knowledge-intensive activities (Filep, 2014). This statement is in close harmony with the idea of Triple-Helix-model (Etzkowitz \& Leydesdorff, 2000).

AUDI Hungária has been playing a prominent role in the economic development of Györ (and Hungary) since 1990. As the biggest employer of the city and the region, the company indirectly provides livelihood to several tens of thousands of people, and has a significant role in Hungary's volume of foreign trade. It is no wonder that the automotive industry, the development of the SME sector related to it, and the extension of supplier capacity always have a major role to play. At the same time, the pursuit of the diversification of the economic structure (e.g. sport economy, environment- and health industry, economic services, tourism), and the close cooperation of the local economy and the university research\&development to catalyse innovation processes, are strongly emphasised in the recent materials (Fekete, 2014).

According to international standards, Györ and its suburban area belongs to the mediumsize city category, so it is worth to examine, why we speak about metropolitan governance in connection with Győr? According to Enyedi's definition the power centres controlling global processes are related to cities agglomerating influential transnational corporations, so not only the size and the population of a city is important, but also the position in the global market and global supply chain. The presence of the world's biggest engine factory and a huge automotive industry centre in Győr grants a significant position of Györ in the global networks. In my opinion, that is an important reason why we should observe metropolitan governance methods in the Győr region.

\section{Economic development}

Former scientific research stated, that directions of cooperation between the economic development organizations in Győr are mainly based on personal or ad hoc relations (Czakó et al., 2017). In Györ the economic environment is probably most significantly developed by the municipality of the city which carries out its economic development activities through its 
own organisation, moreover through its related corporations. Furthermore, there have also been more and more references to the shift towards economic governance. The general assembly of the city of Györ has taken many important measures to boost the economy: since 1 January 2014, the local business tax rate was reduced from $2 \%$ to $1.8 \%$, which is decreased to $1.6 \%$ from 1 January 2018; year after year it ensured the development of economic infrastructure; in the middle of the year 2000 the city channelled the youth towards vocational training by terminating some secondary grammar school classes in order to supply adequate labour, and introduced a grant system for the young ones studying in skills shortages. At the time of the economic crisis of 2008 the city granted job retention support to the SMEs of Győr. While at that time job retention support for the SMEs was important, in these days they are facing increasing difficulties because of the shortage of skilled labour.

Transport development measures have taken place in urban investment by which the more dynamic accessibility of industrial regions within the city has been realised (e.g. Tibormajori Road, Vonal Road). There are now new transport relationships between quarters that were in the past closed from each other (e.g. Jedlik Bridge, Olimpia Bridge) New Bácsai Road and its connection to Szövetség Street resulted in a new East-West traffic relation etc.

The Department of Urban Planning is one of the related organizational units of the municipality of Györ. It is responsible for the coordination and execution of certain infrastructural developments on the one hand, while on the other hand, it has the Chief Architect Group as an operating part, which prepares and develops the town-planning scheme of Győr, and besides its building regulation, makes important preparatory tasks in connection with the possible reclassification of areas intended for economic activities (GYMJVÖK, 2015).

Besides its internal organisation units, the local government disposes of several business organisations or shares in business organisations in the profile of which economic development is given a considerable emphasis. Györ-Szol Zrt. is one of the most important business organisations in Győr which is $100 \%$ owned by the local government. The corporation created in 2010 by merging several municipal companies, actually has 4 boards to carry out its tasks. The Property Management Board is the most significant one from an economic development viewpoint, which can influence the local economic processes through the leasing of local government-owned businesses and the sale of its own territories. The Board also includes the operation of local markets and the market hall, which is an important forum for helping local farmers (gyorszol.hu, 2015).

The Györ International Industrial Park Ltd., which is $100 \%$ owned by the city, offers countless services to companies wishing to settle and also to the ones already operating there. As an important economic development organization, it supports the newly established companies with legal advice, technical preparation, and tender consultancy. For them the site, 
where they can start their operation, is sold by the industrial park. In the recent years Györ has carried out several expansions and infrastructural development in the area, using its own resources and European Union resources, thus roads have been constructed and public works have been built. Moreover, one of the biggest investments of last years was completed: the building of a new side-track. The expansion of the Industrial Park is in progress.

Győr's incubation centre is INNONET Nonprofit Ltd. It was established in 1997, with the determined aim to set up and operate an innovation and technological centre, which activity is still done by the corporation. INNONET provides advisory and IT services to start-up companies with knowledge- and technology intensity and growth potential, as well as tender, project management and technology transfer services to innovative SMEs capable of building up supplier relationships (spin-off). Mobilis Interactive Exhibition Centre plays an important role in career orientation, in attracting young people towards natural sciences and engineering sciences. The career orientation centre has been operated by a joint company of the university and the city since October 2016, which is a further example of the institutionalized cooperation of the city and the university at several levels (Fekete, 2017c).

The government of Hungary has also significantly contributed to the city's infrastructural development from the central government budget in recent times. It is worth mentioning the building of the bypass road around Györ from the East (it will probably be opened for the public in the first half of the year 2018). The industrial areas around AUDI have gained a new traffic connection by this, and from now on the North-South truck traffic will not hit the city centre, but will pass outside the city. Several transport routes have been built, or are still being built by public financing to serve the connection between the city and its region: such as the expressway to Szombathely, the expressway to Sopron which is being built, the bypass being built towards Pápa. These investments also include the reconstruction of several crossroads of restricted capacity in Györ.

\section{Transition towards economic governance}

Many organizations have recently been set up in Györ in connection with the processes of the economic governance of the city. The introduction of the present study outlines that, apart from the development of hard infrastructure, more and more organizations are being established which are functioning not only with the participation of the municipal sector. These organisations have exercised economic influence on the territories over the administrative boundary of the city in order to ensure economic prosperity for the given metropolitan region and also to establish soft infrastructure for sustainable economic development. 
Within the system of the regional relationships of the Györ Municipality the establishment of Arrabona EGTC has resulted in the appearance of new dimensions. Arrabona EGTC became an organization that - together with the municipal government - is institutionalising the regional system of relations of the city towards the Upper Hungary Region in Slovakia and it is also strengthening the cross-border character of the greater city region. EGTC was established in Győr by four founder towns (Győr, Mosonmagyaróvár, Dunaszerdahely, Somorja) on $31^{\text {st }}$ August 2010 (Arrabona EGTC, 2013), the organization has 31 member municipalities at present.

Figure 2 The territory of Arrabona EGTC.

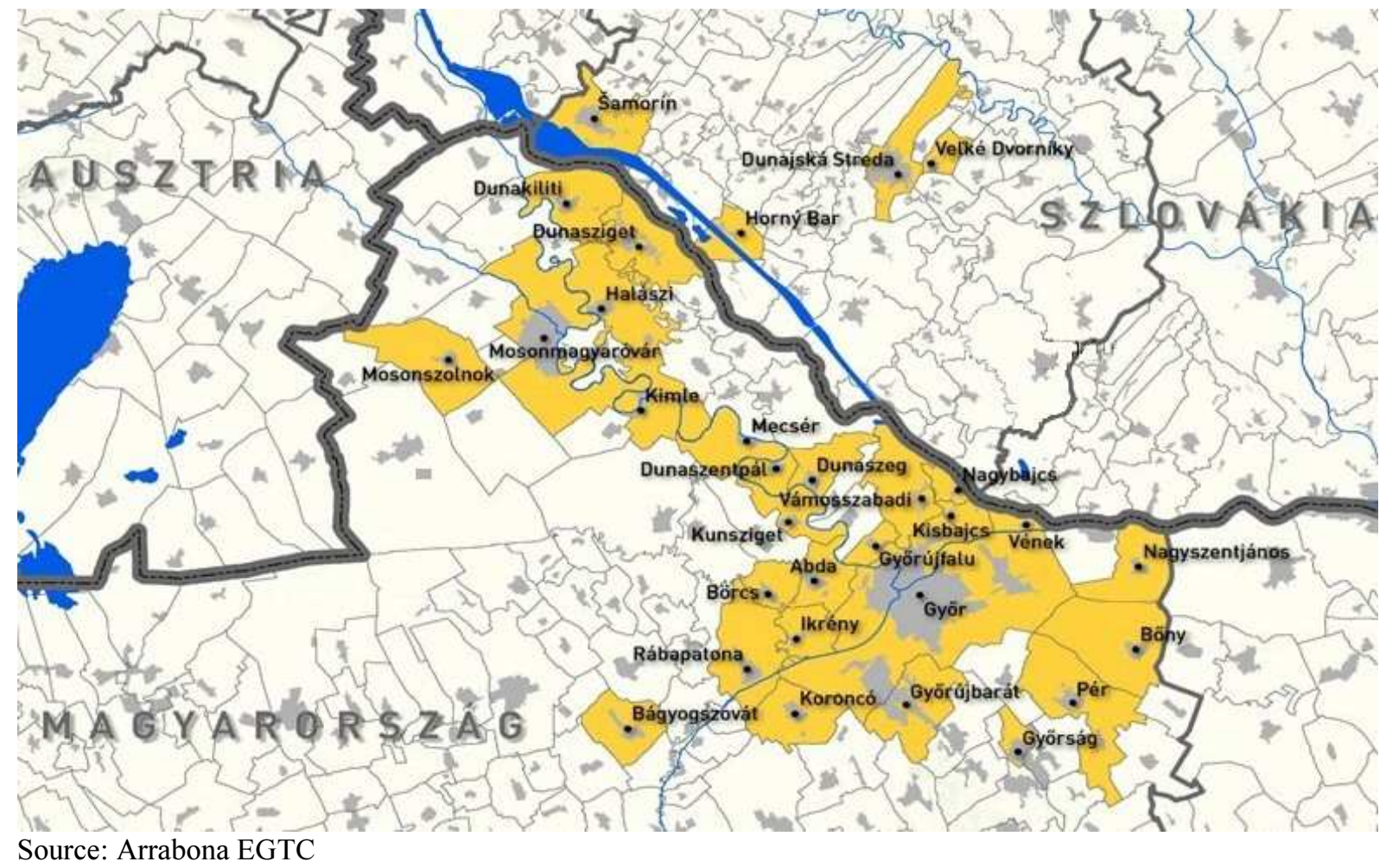

EGTC has submitted several project applications in order to develop the territories in question. Within the framework of the "The setting up the Nagymegyer-Györ scheduled return coach line in order to promote tourism and employment" project a scheduled coach service has been established between Győr and Nagymegyer since 2013. The project is being implemented in the context of "The 2007-2013 Hungary - Slovakia Cross-Border Cooperation Program "and with the assistance of EGTC (innovation.gyor.hu, 2017). According to my opinion Arrabona EGTC will play an important role in positioning Győr in regional and international relations, as the cooperation itself, which was set up in 2010, now has a settled organizational structure. In the past few years Arrabona EGTC managed to make successful improvements in its activities related to project applications and project 
management. The organization participated in the management of EU projects of financial support totalling several thousand million HUF. These are the following: the industrial railway project in the Győr Industrial Park, the construction of the Györ-Gyönyü cycle path and the project to support regional relations in the Györ District (arrabona.eu, 2017). Common developments in tourism are being carried out at present within the framework of the cooperation between Győr and Dunaszerdahely, moreover, the Dunaszerdahely office of EGTC will soon be opened as well.

The initiative "Cooperation for Career Models in the Automotive Industry in Győr" also has many year of experience in the field of cooperation. The meeting of national regions of the automotive industry was also organised as a supplementary programme of the event 'Formula Student Hungary' in August 2014. A common event was organised again in November 2014 at the Automotive Hungary Fair II, then in the course of 2015 the elaboration of future prospects and the factual organizational frame of the career model were started and negotiations were also begun with co-operator circles. The first 'Györ TechTogether Junior' contest was organized within the framework of the cooperation for career models in March 2015. Students of 11 secondary schools of the Northern Hungary Region, who have a keen interest in technology, were participating in the contest and they also had the possibility to start relations with several automotive companies during the day of the competition. In September 2015 the 'Győr Automative Career Forum' was organized within the framework of the "Györ Knowledge Pool" project which had been carried out by the consortium of Széchenyi István University and Győr. At the event future prospects of Győr were outlined in connection with the automotive industry and economic development. The logo, the reference book and the homepage of the 'Györ Automotive Career Model' were completed in the context of the same project, moreover, the 2016 work schedule of the model was drafted as well.

At present the cooperation is being coordinated by the Győr Municipality. After having become institutionalized, the Györ Regional Development and Project Management Ltd. will perform this duty according to the plans. In conformity with the planned agreement for cooperation and according to the regulations of operation and organization the "Györ Automotive Career Model' has four founding members: the Municipality of Győr, Audi Hungaria Ltd., Széchenyi István University and the Győr-Moson-Sopron County Chamber of Trade and Industry. Every future participant will become a secondary member of the cooperation. The cooperation is expected to be officially set up in 2018. Subsequently, the cooperation will be able to play an important role in various significant issues and it will also 
be able to function as a professional workshop when trade conceptions - such as decisions on economic development, the project of rented dwellings, the future of vocational education etc. - are to be prepared for the City and the Government (Fekete, 2017c).

The 'Györ District Employment Pact' was made in 2016 within the framework of the "Local employment co-operations in the Györ District" project. The objectives of the organisation are the followings: to decrease the level of unemployment and labour shortage within the Györ District, to harmonize the conceptions of economic development and vocational education, to start activities for career orientation, to provide training and counselling etc. The management of the consortium concerning the project is represented by the Municipality of Györ, the founding members of the agreement are the following institutions: Győr-Moson-Sopron County Regional Government Agency, Municipality of Győr-Moson-Sopron County, Győr-Moson-Sopron County Camber of Trade and Industry, Győr Regional Development and Project Management Ltd., Győr-Szol Zrt., Széchenyi István University, Mobilis Public Interest Non-Profit Ltd., National Association of Contractors and Employers, St.Cirill and Method Foundation, Association of the Hungarian Charity Service of the Order of Malta (Győr District Employment Pact, 2016).

It can be laid down as a fact in connection with the agreement, that the recent cooperation aims to deal with the issues of the labour market and the field of employment in an institutionalized form particularly on a level that is extended over the borders of the city. The founders are representing all the three spheres of the Triple Helix model in due proportion and this is also characteristic of the Directive group as well.

The Györ Local Community (GYHK), which was founded on the basis of the "Development of the infrastructure of cultural and communal areas and the development of local communities in connection with the local strategies of the city" CLLD-project (Community-led Local Development), represents a new pattern in the system of cooperations. The main objective of the organization, which was set up on the basis of the project, is to accomplish the development of cultural communities and communal areas. Apart from that, GYHK is focusing on the strengthening of the local identity, the establishment of relations between well-functioning but segregated communities, the development of areas provided for the communities, and the integration of the inactive segment of the population into communal life. At present the communal territory of action corresponds to the territory of the City. GYHK is made up of ten members at the moment that are representatives of the state sector (Municipality of Győr, Arrabona EGTC, Rómer Flóris Museum of Arts and History, Dr. Kovács Pál Library and Communal Area), the civilian sector (Győr Aquatic Sports 
Association, Universitas-Györ Foundation, Association of the Újváros Provincialists, For the Győr University Association of Public Interests) and entrepreneurs (Gallery Theatre Nonprofit Ltd., Universitas Arrabona Ltd.). The organization lays emphasis on the representation of the three sectors to the same extent, its operational institution is Arrabona EGTC (Györ Local Community, 2016).

Figure 3 The most important cultural institutions of Györ.

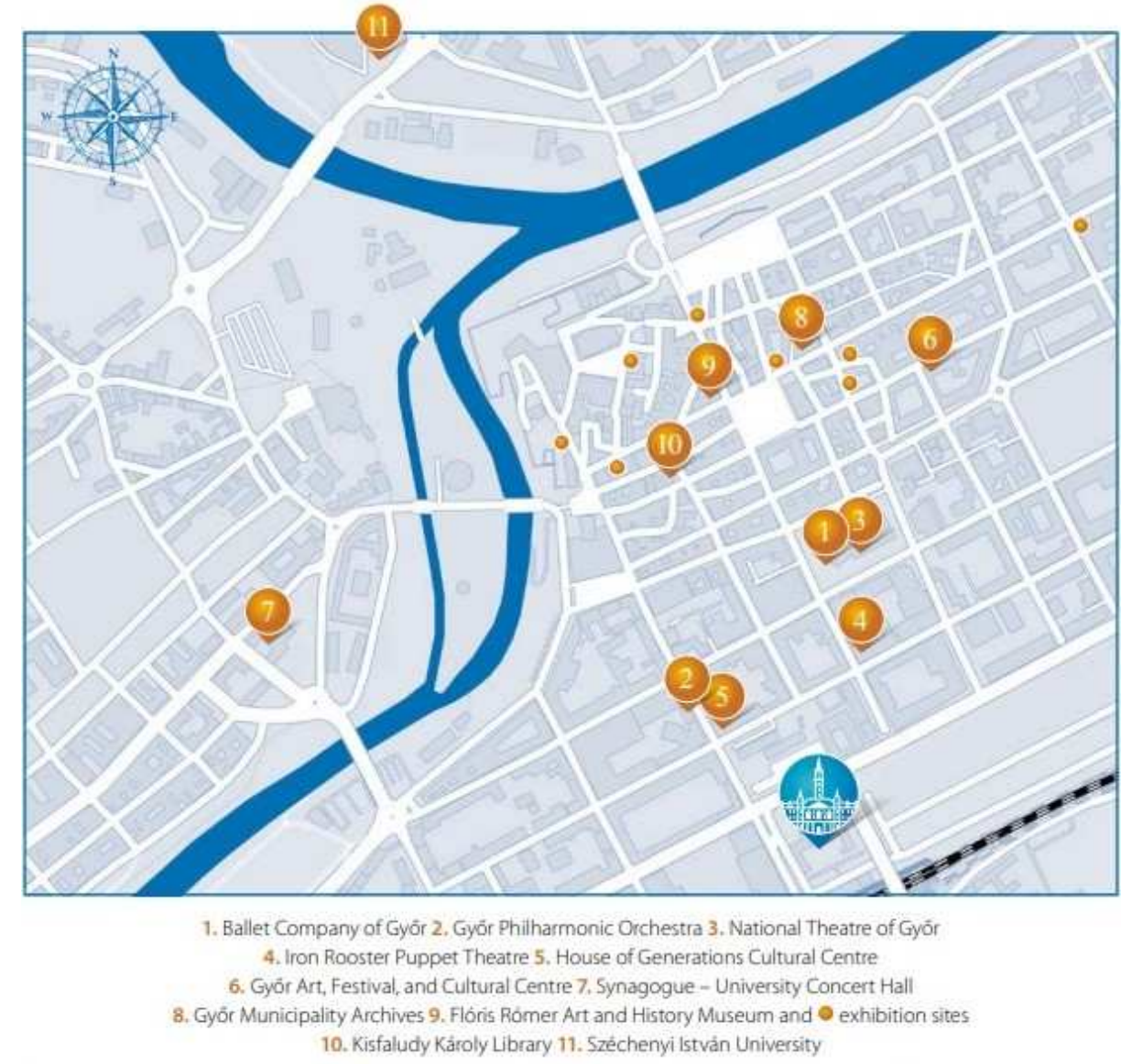

Source: Municipality of Győr

The allocation of the financial support of HUF 750 million will be launched in January 2018 and the organization will begin its operation at the same time. It will be worth paying attention to the operation of GYHK as after a potentially successful competition for the "European Capital of Culture 2023" project the range of activities of the organization can be further broadened by the support of the accomplishment of the project. In order to carry out the complex regional project it will obviously be important to increase the number of the members of the organization with necessary potential participants. Even though it is a recently founded organization, it is crucial to give a short analysis of it as, on the one hand, the organization has close relations with Arrabona EGTC, and on the other hand, in the future it can also become a potential factor of the metropolitan governance of the cultural life in Györ. 
Table 3 The comparison of the participants of the economic governance of Györ

\begin{tabular}{|c|c|c|c|c|}
\hline & $\begin{array}{l}\text { Focuses on the } \\
\text { city and the } \\
\text { region }\end{array}$ & $\begin{array}{l}\text { Co-operations } \\
\text { withstate-, } \\
\text { economic-and } \\
\text { scientific sectors }\end{array}$ & $\begin{array}{l}\text { Sustainability, } \\
\text { financing }\end{array}$ & $\begin{array}{l}\text { Sectors of the } \\
\text { economy }\end{array}$ \\
\hline CLLD & $\begin{array}{l}\text { Partly } \\
\text { Györ is the } \\
\text { only clear-cut } \\
\text { target territory } \\
\text { for CLLD (but } \\
\text { Arrabona } \\
\text { EGTC is a } \\
\text { member) }\end{array}$ & Yes & $\begin{array}{l}\text { Long-term } \\
\text { sustainability } \\
\text { depends basically } \\
\text { on EU support }\end{array}$ & Yes (culture) \\
\hline EGTC & $\begin{array}{l}\text { Yes } \\
\text { (international) }\end{array}$ & $\begin{array}{l}\text { No (local } \\
\text { authorities alone) }\end{array}$ & $\begin{array}{l}\text { It has been } \\
\text { functioning for } \\
\text { many years - } \\
\text { members deposit } \\
\text { payments }\end{array}$ & It is not revealing \\
\hline $\begin{array}{l}\text { Győr } \\
\text { Automotive } \\
\text { Career Model } \\
\text { Cooperation }\end{array}$ & Partly & Yes & Unknown & $\begin{array}{l}\text { Yes (automotive } \\
\text { industry) }\end{array}$ \\
\hline Employment Pact & $\begin{array}{l}\text { Yes (of the } \\
\text { district) }\end{array}$ & Yes & $\begin{array}{l}\text { Long-term } \\
\text { sustainability } \\
\text { depends basically } \\
\text { on EU support }\end{array}$ & No \\
\hline
\end{tabular}

Source: own editing

Tab. 3 summarises the results of the research in connection with the organizations in Györ that can constitute the basis of the metropolitan economic governance of the city of Györ. In my opinion, the four aspects of the summary (regional focus, members, sustainability, economic sectors) are suitable for the researchers to draw conclusions concerning the present system of institutions. The research of the regional focus can give an answer to the questions of authority in a big city: it is obvious that presently Arrabona EGTC and the Employment Pact have clear regional focuses (moreover, the former has international influence) while CLLD and the 'Györ Automotive Career Models' in Györ only partly have this attribute. For three of the four participants, except for EGTC, the cooperation exists between the state-, economic- and scientific-sectors, and examples for the participation of civil society organizations exist as well. In terms of sustainability only Arrabona EGTC has so far proved to be able to function on the basis of the payments of its members or outsider resources. As far as the other three institutions are concerned there is not enough information regarding sustainability (the reason for this, obviously, is that the other three co-operations have only recently been founded). It can be stated on the basis of the comparison that Arrabona EGTC 
and the Employment Forum can deal with a wide range of subjects but the 'Györ Automotive Career Model' and the 'Györ Local Community' focus on a particular sector (automotive industry and cultural life respectively). It is important to mention here that the latter two have limited abilities to participate in the economic governance of the city because their subjects are restricted (it is especially the characteristic of GYHK, which represents the cultural sphere; they can be interconnected in the fields of the creative economy).

\section{CONCLUSION, AN OUTLOOK}

After having examined the processes in economic development and economic governance in Györ, it can be stated, that both segments can be perceptible in the management of the city in various ways. Activities observed in Győr can strengthen the view-point, which was discussed in the introduction, i.e. the processes of economic development and economic governance have nowadays been going on in parallel with each other. Moreover, the co-ordinating activities of local authorities can be observed in the work of organizations that support economic governance. In the course of the research it was also confirmed, that built infrastructure can serve as a fundamental condition for the cooperation of network-systems, that operate the governance system of a municipality. This happened for instance in case of Mobilis in Győr, which institution - apart from its function as an exhibition area and equipment for experiments - was able to become a centre of occupational guidance in order to generate cooperation between the institutions of vocational training and enterprises. After the premises of INNONET Ltd. had been built, it became capable of operating as an incubation centre, and it is serving new enterprises that are now functioning in the Industrial Park.

While examining the future prospects of Györ, it can be stated, that the course of proceedings, which determine the future of the city, aim to support social and economic innovation. In consequence of their significance various programmes are going to play an important role and they will have an impact on the future of the city. Among others the following programmes represent proper examples: the 'Modern Cities Programme' (Fekete, 2017) and the 'Higher Education and Industry Cooperation Centre' (Fekete, 2017b) serving as a basis for transition towards cultural and sport economy and research \&development. The sport hotel located in the Olympic Sports Park can be built within the frameworks of the 'Modern Cities Programme' and it provides significant help to strengthen the revenue producing function of the sports infrastructure, which was set up for the 2017 European Youth Olympic Festival (EYOF). The buildings of the Györ National Theatre are to be renewed also 
within the framework of this programme, moreover, a modern concert hall and conference centre will also be built. These developments are going to serve innovations in the fields of the cultural and creative economy together with the '2023 European Capital of Culture' scheme. The establishment of the 'Higher Education and Industry Cooperation Centre' is presently being carried out and, as a consequence of the process, new laboratories and equipment will be supplied for the R\&D potential of Széchenyi István University. Moreover, on the basis of common product development and the organizational development of SMEs, the development of new methodology will also be carried out to improve the international competitiveness of the SMEs. The Digital Competence Centre, as one of the components of the 'Modern Cities Programme', will establish a new connection between university and industry, moreover, it can also contribute to the rehabilitation process of its site, a brownfield area of the former National Company of Biscuit and Wafer Factory of Győr.

\section{Acknowledgements}

Supported by "Internationalisation, initiatives to establish a new source of researchers and graduates, and development of knowledge and technological transfer as instruments of intelligent specialisations at Széchenyi István University" project, EFOP-3.6.1-16-2016-00017.

\section{REFERENCES}

Arrabona EGTC (2013): Az Arrabona EGTC bemutatkozása. (Introduction of Arrabona EGTC). Győr

arrabona.eu (2017): Hírek. (News). Retreived on 1 March 2017 from http://arrabona.eu/hirek.html.

Ash, A. (1999): An Institutionalist Perspective on Regional Economic Development. International Journal of Urban and Regional Research, 23, 2, 365-378.

Ayuso, A., \& Coll, J. M. (2016): The Role of Metropolitan Areas in the Governance of Development Challenges: Towards the European Urban Agenda. European Metropolitan Authorities, Policy Paper, CIDOB- Barcelona Centre for International Affairs

Bacsi, Z. (2017): Tourism and diversity. Deturope, 9, 2: 25-57.

Bajmócy, Z. (2011): Bevezetés a helyi gazdaságfejlesztésbe. (Introduction to local economic development). JATEPress, Szeged

Bajmócy, Z., Gébert, J., - Málovics, G. (2017): How to evaluate local economic development projects from a people-centred perspective? An analytical framework based on the capability approach. Deturope, 9, 2, 4-24.

Bartik, T. J. (1991): Who Benefits from State and Local Economic Development Policies? Kalamazoo, MI: W.E. Upjohn Institute for Employment Research.

Brenner, N. (2003): Standortpolitik, State Rescaling and the New Metropolitan Governance in Western Europe. The Planning Review, 39, 152, 15-25.

Crouch, C. (2011): Competitive cities and problems of democracy. In: Pike, AndyRodríguez-Pose, Andrés- Tomaney, John (szerk.): Handbook of Local and Regional Development. Routledge, London. 295-305. o.

Czakó, K. (2014): Az Audi Hungaria Motor Kft. hatása a helyi gazdasági és társadalmi folyamatokra. (Audi Hungaria Motor Kft. in the local economy). Tér és társadalom, 28, 2, 189-198. 
Czakó, K., Kecskés, P., \& Reisinger A. (2017): Services of economic development organisations in Győr. Deturope, 9, 3, 85-100.

Desai, S.- Nijkamp, P.- Stough, R. R. (2011): New directions in regional economic development: an introduction. In: Desai, Sameeksha- Nijkamp, Peter- Stough Roger R. (szerk.): New Directions in Regional Economic Development. The Role of Entrepreneurship Theory and Methods, Practice and Policy. Edward Elgar Publishing Limited, Cheltenham. 3-12. o.

Enyedi, Gy. (2012): Városi világ. (Urban world). Akadémiai Kiadó, Budapest

Etzkowitz, H., \& Leydesdorff, L. (2000): The dynamics of innovation: from National Sytems and „Mode 2" to a Triple Helix of university-industry-government relations. Research policy, 29., 109-123. o.

Faragó, L. (2006): A városokra alapozott területpolitika koncepcionális megalapozása. (Conceptional Establishment of Town Based Regional Politics). Tér és Társadalom, 20, 2, 83-102.

Feiock, R. C. (2004): Introduction: Regionalism and Institutional Collective Action. In R. C. Feiock (Ed.), Metropolitan Governance: Conflict, Competition and Cooperation (pp. 316.) Georgetown University Press, Washington D.C.

Fekete, D. (2014): Győr aktuális jövőképe a város stratégiai dokumentumainak tükrében. (Current vision of Györ according to the city's strategic documents). In T. Dusek (Ed.) A városi rendszer müködése: Közösségi szféra, oktatás és Győr jövőképe (pp. 180-187.) Universitas-Győr Nonprofit Kft.

Fekete, D. (2017a): A Modern Városok Program elemzési lehetőségei. (Costs of the Modern Cities Programme Analysis). Polgári Szemle, 13, 1-3, 94-105.

Fekete, D. (2017b): Felsőoktatási és Ipari Együttműködési Központ Győrben. (Higher Education and Industrial Cooperation Centre in Győr). Polgári Szemle, 13, 1-3, 106115.

Fekete, D. (2017c): Nagyvárosi régiók gazdasági kormányzása: Új megközelitések európai jármüipari központok elemzésével. (Economic Governance of Metropolitan Regions. New approaches in analysing European automotive industry centres). Dissertation, Széchenyi István Egyetem

Filep, B. (2014): A nagyvárosok az európai és a magyar területi politikában. (Cities in the European and Hungarian spatial policy). Publikon Kiadó, Pécs-Győr

Filep, B., Kovács, Z., Kara, A., Tömböly, T. (2013): "City - University - Company" Coordinated Strategic Development: Industry Zone in Győr Focused on the Vehicle Industry. In V. Dermol, N. T. Sirca, G. Đaković (Ed.), Active Citizenship by Knowledge Management \& Innovation: Proceedings of the Management, Knowledge and Learning (pp. 797-808).

GYMJVÖK (Győr Megyei Jogú Város Önkormányzatának Közgyülése) (General assembly of the city of Györ) (2015): Györ Megyei Jogú Város Önkormányzata Szervezeti és Müködési Szabályzata. (Organizational and operational rules of the Municipality of Győr). Győr

Győri Helyi Közösség (Győr Local Community) (2016): Helyi Közösségi Fejlesztési Stratégia 2014-2020. (Local Community Development Strategy 2014-2020.). Győr

Győri Járási Foglalkoztatási Paktum (Győr District Employment Pact) (2016): Együttmüködési megállapodás. (Cooperation agreement). Győr

gyorszol.hu (2015): Szolgáltatások. (Services). http://gyorszol.hu/index.asp?i=szolg. Downloaded: 10 December 2015

Herrschel, T., \& Newman, P. (2002): Governance of Europe's City Regions. Planning, policy and politics. Routledge, London

innovacio.gyor.hu (2017): Nagymegyer-Györ retúr buszjárat.(Győr-Nagymegyer return bus service). http://innovacio.gyor.hu/cikk/nagymegyer_gyor_retur_buszjarat.html. Downloaded: 1 March 2017

Jessop, B. (1997): The entrepreneurial city: re-imaging localities, redesigning economic governance, or restructuring capital?' In. Jewson, N.- MacGregor, S. (eds): Realising Cities: New Spatial Divisions and Social Transformation, London: Routledge, 28-41. 
Knieling, J. (2014): Metropolitan Regions Definitions, Typologies and Recommendations for Development Cooperation. Deutsche Gesellschaft für Internationale Zusammenarbeit (GIZ), Bonn-Eschborn

Korsós, L. (2017): Megyei Jogú Városok helyi adóztatásának, saját és megosztott adóbevételeinek alakulása számokban. (The evolution of the cities with county rights local taxation, their own and divided tax revenue in numbers) (2014-2015-2016. évek.). Eger

KSH (2015): Magyarország közigazgatási helynévkönyve, (Gazetteer of Hungary) 2015. január 1. XLS táblázat. Központi Statisztikai Hivatal, 2015. szeptember 3. Downloaded: 1 March 2017

Lefèvre, C. (1998): Metropolitan Government and Governance in Western Countries: A Critical Review. International Journal of Urban and Regional Research, 1, 9-25.

Lengyel, I. (2010): Regionális gazdaságfejlesztés. Versenyképesség, klaszterek és az alulról szervezödö stratégiák. (Regional economic development. Competitiveness, clusters, bottom-up strategies). Akadémiai Kiadó, Budapest

Lengyel, I., \& Rechnitzer, J. (2004): Regionális gazdaságtan. (Regional economics). Dialóg Campus Kiadó, Pécs-Budapest

Massey, D. S. (1988): Economic Development and International Migration in Comparative Perspective. Population and Development Review, 14, 3, 383-413.

Mattoon, R. H. (1995): Can alternative forms of governance help metropolitan areas? Economic Perspectives, Nov-Dec, 20-32.

Montalvo, J. G., \& Reynal-Querol, M. (2005): Ethnic diversity and economic development. Journal of Development Economics, 76, 2, 293-323.

Moon, M. J. (2001): Cultural Governance. A Comparative Study of Three Cultural Districts. In: Administration \& Society, (33) 432-454. o.

Oakerson, R. J. (2004): The Study of Metropolitan Governance. In R. C. Feiock (Ed.), Metropolitan Governance: Conflict, Competition and Cooperation (pp. 17-45.) Georgetown University Press, Washington D.C.

Ostrom, E. (2010.): Beyond Markets and States: Polycentric Governance of Complex Economic Systems. American Economic Review, 100, 3, 641-672.

Pálné Kovács, I. (1999): Regionális politika és közigazgatás. (Regional policy and public administration). Dialóg Campus Kiadó, Budapest-Pécs

Pálné Kovács, I. (2008): Az új várospolitika kormányzási filozófiája. (Governance Philosophy of the New Urban Policy). Tér és társadalom, 22, 1, 45-57.

Pike, A., Rodríguez-Pose, A., \& Tomaney, J. (2007): What Kind of Local and Regional Development and for Whom?, Regional Studies, 41, 9, 1253-1269.

Porter, M. E. (2000): Location, competition, and economic development: Local clusters in a global economy. Economic Development Quarterly, 1. sz. 15-34. o.

Rechnitzer, J. (2016): A területi tőke a városfejlödésben- A Györ-kód. (The territorial capital in city development. The Győr Code). Dialóg Campus Kiadó, Pécs-Budapest

Rechnitzer, J., \& Smahó, M. (2011): Területi politika. (Spatial policy). Akadémiai kiadó, Budapest.

Salet, W., Thornley, A., \& Kreukels, A. (2003): Practices of metropolitan governance in Europe: experiences and lessons. In.: Salet, W. Thornley, A., \& Kreukels, A. (eds): Metropolitan Governance and Spatial Planning. Spon Press, Taylor and Francis, London and New York, 377-391.

Somlyódyné Pfeil, E. (2008): A városi térségek a közigazgatási struktúra és a „governance” keresztmetszetében. (Urban Areas in the Focus of Administrational Structure and Urban Govemance). Tér és társadalom, 22(1), 27-43.

Somlyódyné Pfeil, E. (2011): Az agglomerációk jelentőségének változása az államszervezés és a városi kormányzás szempontjából. (The changing significance of agglomerations in light of state spatial organisation and regional governance). Tér és Társadalom, 25(3), 27-59. 